Article

\title{
Influence of Congruency between Ideal Self and Brand Image on Sustainable Happiness
}

\author{
Jeongsoo Han ${ }^{1}$, Mina Jun ${ }^{2, *}$, Miyea Kim ${ }^{3}$ and Sookyoung Key ${ }^{4}$ \\ 1 Business School, Sogang University, 35 Baekbeom-ro, Mapo-gu, Seoul 04107, Korea; js3916@sogang.ac.kr \\ 2 Business School, Korea University, 145 Anam-Ro, Seongbuk-Gu, Seoul 02841, Korea \\ 3 Department of Consumer Economics, Sookmyung Women's University, 47gil, Yongsan-gu, \\ Seoul 04310, Korea; miyeakim@sookmyung.ac.kr \\ 4 Business School, Sungkyunkwan University, 25-2 Sungkyunkwan-ro, Jongno-gu, Seoul 03063, Korea; \\ keynde14@skku.edu \\ * Correspondence: phdmina@korea.ac.kr; Tel.: +82-109-178-6970
}

Received: 16 October 2018; Accepted: 3 November 2018; Published: 7 November 2018

\begin{abstract}
Building on the Sustainable Happiness Model, this study examines how congruency between ideal self-concepts and brand image influences a sense of happiness. The findings show that when the ideal self-image and the ideal social self-image are congruent with brand image, a sense of happiness can be enhanced through brand identification and positive emotions. An additional two-mediation analysis confirms that there are full mediation effects of brand identification and positive emotions between ideal self/ideal social self-brand congruency and happiness. This study contributes to the literature as it reveals the mechanism of how congruency between ideal self-concepts and brand image positively affects happiness. In addition, this study also provides useful insights for business practitioners as previous studies suggest that enhancing consumer well-being helps increase firms' long-term sustainability in many ways.
\end{abstract}

Keywords: Sustainable happiness model; ideal self; ideal social self; brand identification; positive emotions; consumer well-being

\section{Introduction}

Happiness is a common pursuit of value for all human beings, and people strive for happiness in a variety of ways. Some people seek happiness through their work, and others seek happiness through relationships with family members or friends. Others find happiness through leisure time alone. In this regard, prior studies have attempted to reveal how to increase happiness. For example, the Sustainable Happiness Model [1] suggests that it is effective to express the ideal-self as one of the ways to continuously raise and maintain a sense of happiness.

Improving the happiness of consumers has also drawn much attention from business researchers. Kotler et al. [2] argues that a company's marketing activities should move in the direction of moving people's hearts and improving the quality of life. As a good example of these efforts, Nike, through Michael Jordan, has made it possible for consumers to express their imagination beyond their limits for what they want. Therefore, building on the Sustainable Happiness Model, we expect that a company's marketing efforts can positively influence consumer happiness by reflecting consumers' ideal self-concepts through brands. Specifically, we expect that congruency between ideal self-image and brand image is likely to influence brand identification, which in turn enhances a sense of happiness through positive emotions. In this regard, a main objective of this study is to reveal the mechanism of how the congruency of the consumers' ideal self-concepts and the brand image enhances consumer happiness through brand identification and positive emotions. 
Revealing how to enhance the well-being of consumers through business practices is significant, as extant literature has identified enhancing customer well-being as helping firms to achieve higher financial performance in the long-term [3-6]. In this regard, we believe that our findings provide useful insights for business practitioners to increase the sustainability of their business.

\section{Theoretical Background and Hypotheses}

The Sustainable Happiness Model posits that a person's chronic happiness level can be increased and then sustained [1,7]. Specifically, the Sustainable Happiness Model proposes that visualizing the ideal self-concept is one of the effective ways to enhance a sense of happiness. Self-concept refers to the cognitive and affective understanding of who and what we are [8-10]. As a person's self-concept is important, it has been studied from a multidimensional point of view in psychology as well as in business research. Sirgy [10] suggests multiple dimensions of self-concept, which are actual self, social self, ideal self, and ideal social self. In the business studies, self-congruency, which refers to a fit between the consumer's self and the brand's image, has drawn much attention because extant studies show that the self-congruency can enhance brand performances in many ways [10-13]. By applying the Sustainable Happiness Model to the business context, we expect that ideal self-congruency, a fit between the consumer's ideal self-concepts (ideal self and ideal social self) and brand image, is likely to help increase the feeling of happiness.

As previous studies suggest, consumers tend to connect their self-concepts with a brand image and thus identify themselves with the brand that is congruent with their self-concepts [11,13]. That is, it is a common way for consumers to express themselves through the brands they use. For example, some wealthy consumers use luxury brands such as Channel to express their social and economic status.

We expect that the ideal self/ideal social self-congruency is likely to enhance consumers' identification with the brand. Brand identification is defined as people perceiving and defining themselves according to the attributes of the brand [14]. In other words, brand identification is the perception of sameness between the brand and consumer [15]. For instance, Kim et al. [16] found that people are more likely to feel brand identification as the brand expresses their self-concepts. In line with this, Stokburger-Sauer et al. [17] also suggests that brand-self similarity is a determinant of brand identification.

While actual self-congruency and ideal self-congruency are both important, some studies compare the differential impacts of them on consumers. Of the multidimensional self-concepts, Wetzel and Insko [18] and Herbst [19] suggest that reflecting ideal self-concept is a stronger predictor for brand identification than reflecting the actual self-concept. That is, people can be more attractive to brands reflecting their ideal self than actual self. LaPrelle et al. [20] also shows that people try to have a stronger relationship with a person who shows their ideal self than a person who shows their actual self. Based on the argument, we propose the following hypotheses.

Hypothesis 1. Congruency between ideal self and brand image will be positively associated with brand identification.

Hypothesis 2. Congruency between ideal social self and brand image will be positively associated with brand identification.

The self-expansion theory posits that people have an innate need to incorporate others into their self-concepts [21]. Based on previous studies in branding, we expect that building relationships with brands, like brand identification, is likely to fulfill the innate needs of self-expansion for consumers. Fournier [22] suggests that a relationship between a consumer and a brand is very similar to a relationship with other people. Even though the relationship between the consumer and the brand is not interpersonal, brands can play the role of the "other", with whom the consumer identifies [22] 
(p. 346). It is because consumers tend to build powerful relationships with brands when the brands express their identities [23].

Thus, we expect that brand identification, which can fulfill the needs of self-expansion through the relationship with brands, is likely to evoke positive emotions for consumers. Prior studies support this view. For example, Patrick et al. [24] examines the relationship between need fulfillment and well-being. They find that need fulfillment was associated with more positive emotions and less negative emotions. Branscombe and Wann [25] also find that a strong sense of unity with their favorite sports team can eliminate depressed emotions and alienation, which results in the increasing of self-worth. Based on the argument, we propose the following hypothesis.

Hypothesis 3. Brand identification will be positively associated with positive emotions.

Emotions are composed of various reaction tendencies [26]. A high level of positive emotion is a positive energy, a strong concentration, and a positive attitude to the task at hand, while a low level of positive emotion is negative for sadness, lethargy, bitterness, and immediate situation [27]. Positive emotions also increase brain dopamine [28]. Positive emotions broaden attention and cognition [29], which facilitates coping with stress and adversity [30]. In addition, positive emotions increase the likelihood of finding positive meaning in both ordinary events and adversity $[31,32]$. The relationship between positive emotions and positive meaning is reciprocal because positive meaning also triggers positive emotions [32].

Based on this, Fredrickson [32] proposes the broaden-and-build model of positive emotions. According to the broaden-and-build theory model, positive emotions broaden new ideas and activities, and promote personal wealth, such as social support and spirited passion. The enhancement and strengthening of these psychological resources have a positive impact on physical and mental health [32,33]. In line with this, those who experience high levels of positive emotions experience less mental and psychological difficulty or suffering [34].

Happiness can be defined as consisting of three components: Frequent positive affect, infrequent negative affect, and a high level of life satisfaction [35]. Considering the nature of happiness, we expect that positive emotions are likely to enhance a sense of happiness by helping people feel more positive emotions and less negative emotions. Therefore, the following hypothesis is proposed

Hypothesis 4. Positive emotions will be positively associated with happiness.

Figure 1 shows our proposed conceptual model of this study, which portrays the influence of congruency between ideal self-concepts and brand image on consumer happiness through brand identification and positive emotions.

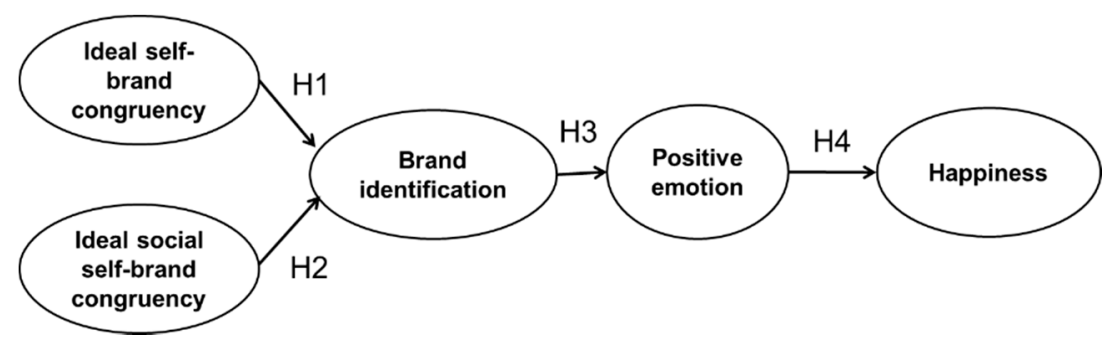

Figure 1. Conceptual framework.

\section{Methods}

\subsection{Participants and Procedure}

In order to select brands for our experiment, we first compiled the list of Interbrand's "Global Top 100 brands", which is one of most reliable sources for the brand-ranking list. Among the candidate 
brands, we selected the final eight brands for an experiment. The selected brands for our study were Facebook, Coca-Cola, Google, Apple, Mercedes-Benz, Disney, Starbucks, and Nike. A survey was conducted on undergraduate students at a major university in Seoul, Korea, by using the selected brands. Participants were given extra credits for their respective class as an incentive.

The participants were randomly assigned to one of the eight selected brands and asked to indicate their familiarity with the brand using seven-point Likert scales [36]. Samples with an average familiarity of less than 4.0 were removed. Through this process, a total of 180 usable respondents were collected. Of the respondents, $52.9 \%$ were male and $47.1 \%$ were female.

In the main experiment, participants were asked to describe the image of the brand, the ideal self-image, and ideal social self-image. Then, they were asked to indicate the degrees of congruency between the brand image and their ideal self-image and between the brand image and their ideal social self-image, respectively. Then, we measured brand identification, positive emotions, and happiness.

\subsection{Measures}

The measurement items for this study were adapted from previous studies and all of the constructs were measured using seven-point Likert scales anchored by "strongly disagree" and "strongly agree".

The measurement items used to measure the ideal self-brand image congruency are: "The image of brand expresses the ideal image of myself", "The image of this brand is consistent with how I would like to be", "The image of this brand is mirror image of the person I would like to be", and "The image of this brand is consistent with the values I consider ideal" $[13,37]$. The measurement items used to measure the ideal social self-brand image congruency are: "The image of this brand is consistent with how I would like to present myself to others", "The image of this brand is mirror image of the person I would like to present myself to others", "The image of this brand expresses myself that others think to be ideal", and "The image of this brand is consistent with the values that others consider ideal". The Cronbach's Alpha value of the constructs were 0.933 and 0.913 , respectively.

The measurement items of brand identification are: "When someone praises this brand it feels like a personal compliment", "I am very interested in what others think about this brand", "I feel good when I see a positive report in the media about this brand", and "If the media evaluates this brand badly, I am in a bad mood" [38]. The Cronbach's Alpha value of the construct was 0.881 .

The measurement items of positive emotions are: "When I use this brand I feel fulfilled/pleased/joyful/excited/amazed" [39]. The Cronbach's Alpha value of construct was 0.914.

The measurement items of happiness are: "In most ways my life is close to my ideal", "The conditions of my life are excellent", "If I could live my life over, I would change almost nothing", "In general, I consider myself very happy", and "Compared to most of my peers, I consider myself more happy" [40,41]. The Cronbach's Alpha value of the construct was 0.899. Table 1 shows the measurement items and the Cronbach's Alpha value for each construct.

Table 1. Measurement items and Cronbach's $\alpha$.

\begin{tabular}{clc}
\hline \multicolumn{1}{c}{ Measures } & \multicolumn{1}{c}{ Items } & Cronbach's $\alpha$ \\
\hline $\begin{array}{c}\text { Ideal self-brand } \\
\text { congruency }\end{array}$ & $\begin{array}{l}\text { The image of brand expresses the ideal image of myself } \\
\text { The image of this brand is consistent with how I would like to be } \\
\text { The image of this brand is mirror image of the person I would like to be } \\
\text { The image of this brand is consistent with the values I consider ideal }\end{array}$ & 0.933 \\
\hline \multirow{2}{*}{$\begin{array}{l}\text { Ideal social } \\
\text { self-brand }\end{array}$} & $\begin{array}{l}\text { The image of this brand is consistent with how I would like to present } \\
\text { myself to others }\end{array}$ & $\begin{array}{l}\text { The image of this brand is mirror image of the person I would like to } \\
\text { present myself to others } \\
\text { The image of this brand expresses myself that others think to be ideal } \\
\end{array}$ \\
& $\begin{array}{l}\text { The image of this brand is consistent with the values that others } \\
\text { consider ideal }\end{array}$ & 0.913 \\
\end{tabular}


Table 1. Cont.

\begin{tabular}{clc}
\hline Measures & \multicolumn{1}{c}{ Items } & Cronbach's $\alpha$ \\
\hline \multirow{2}{*}{$\begin{array}{c}\text { Brand } \\
\text { identification }\end{array}$} & $\begin{array}{l}\text { When someone praises this brand, it feels like a personal compliment } \\
\text { I feel good when I see a positive report in the media about this brand } \\
\text { If the media evaluates this brand badly, I am in a bad mood }\end{array}$ & 0.881 \\
\hline \multirow{2}{*}{$\begin{array}{l}\text { Positive } \\
\text { emotions }\end{array}$} & When I use this brand, I feel fulfilled & \\
& When I use this brand, I feel pleased & 0.914 \\
& When I use this brand, I feel joyful & \\
& When I use this brand, I feel excited & \\
& In most ways my life is close to my ideal & 0.899 \\
& The conditions of my life are excellent \\
Happiness & If I could live my life over, I would change almost nothing \\
& In general, I consider myself very happy \\
& Compared to most of my peers, I consider myself more happy & \\
\hline
\end{tabular}

\section{Results}

\subsection{Hypotheses Test}

To test the reliability of the major constructs, we examined Cronbach's Alpha values of them. All Cronbach's Alpha values are greater than 0.70, indicating that the construct measures embody internal consistency. To test the validity of the constructs used in this study, especially in terms of convergent and discriminant validity, we conducted a confirmatory factor analysis (CFA) by using AMOS program. The model fits $(\mathrm{CMIN} / \mathrm{DF}=2.111, \mathrm{CFI}=0.929, \mathrm{IFI}=0.930, \mathrm{TLI}=0.917, \mathrm{NFI}=0.879$, and RMSEA $=0.081$ ) generally satisfy the required level. As to the convergent validity, all the factor loadings of measurement items for the constructs turned out to be significant $(t \geq 1.96)$. In addition, the values of composite reliability for each construct are greater than 0.7 , which means that the construct reliability is sufficient. Table 2 shows the results of CFA.

As to the discriminant validity, as shown in Table 3, all the values of Average Variance Extracted (AVE) for each construct exceed the squared correlations between all pairs of constructs [42]. Therefore, we also confirmed that the degree of discriminant validity for all constructs is sufficient.

In summary, our results of analysis indicated that our measurement items of the constructs are reliable and valid to test our hypothesized model.

Table 2. Result of confirmatory factor analysis.

\begin{tabular}{|c|c|c|c|c|}
\hline \multicolumn{5}{|c|}{ Confirmatory Factor Analysis (CFA) } \\
\hline Constructs & & Estimate ( $t$-Value) & Composite Reliability & AVE \\
\hline \multirow{4}{*}{ Ideal self-brand congruency } & 1 & 0.874 & \multirow{4}{*}{0.867} & \multirow{4}{*}{0.620} \\
\hline & 2 & $0.906(17.321)$ & & \\
\hline & 3 & $0.903(17.226)$ & & \\
\hline & 4 & $0.848(15.235)$ & & \\
\hline \multirow{4}{*}{ Ideal social self-brand congruency } & 1 & 0.890 & \multirow{4}{*}{0.859} & \multirow{4}{*}{0.606} \\
\hline & 2 & $0.916(18.028)$ & & \\
\hline & 3 & $0.866(16.184)$ & & \\
\hline & 4 & $0.743(12.268)$ & & \\
\hline \multirow{4}{*}{ Brand identification } & 1 & 0.736 & \multirow{4}{*}{0.791} & \multirow{4}{*}{$0.48 \mathrm{~s}$} \\
\hline & 2 & $0.749(9.989)$ & & \\
\hline & 3 & $0.936(12.350)$ & & \\
\hline & 4 & $0.826(11.092)$ & & \\
\hline
\end{tabular}


Table 2. Cont.

\begin{tabular}{|c|c|c|c|c|}
\hline \multicolumn{5}{|c|}{ Confirmatory Factor Analysis (CFA) } \\
\hline Constructs & & Estimate ( $t$-Value) & Composite Reliability & AVE \\
\hline \multirow{4}{*}{ Positive emotions } & 1 & 0.754 & \multirow{4}{*}{0.843} & \multirow{4}{*}{0.576} \\
\hline & 2 & $0.794(11.096)$ & & \\
\hline & 3 & $0.916(13.077)$ & & \\
\hline & 4 & $0.934(13.314)$ & & \\
\hline \multirow{5}{*}{ Happiness } & 1 & 0.752 & \multirow{5}{*}{0.845} & \multirow{5}{*}{0.522} \\
\hline & 2 & $0.814(11.071)$ & & \\
\hline & 3 & $0.742(9.985)$ & & \\
\hline & 4 & $0.863(11.778)$ & & \\
\hline & 5 & $0.848(11.568)$ & & \\
\hline
\end{tabular}

Table 3. Correlation, square of correlation between variables, and AVE.

\begin{tabular}{cccccc}
\hline & $\mathbf{1}$ & $\mathbf{2}$ & $\mathbf{3}$ & $\mathbf{4}$ & $\mathbf{5}$ \\
\hline Ideal self-brand congruency & 0.620 & 0.226 & 0.215 & 0.142 & 0.010 \\
Ideal social self-brand congruency & $0.475^{* *}$ & 0.606 & 0.137 & 0.106 & 0.001 \\
Brand identification & $0.464^{* *}$ & $0.371^{* *}$ & 0.489 & 0.334 & 0.024 \\
Positive emotions & $0.377^{* *}$ & $0.327^{* *}$ & $0.578^{* *}$ & 0.576 & 0.038 \\
Happiness & $0.104^{*}$ & 0.033 & $0.156^{*}$ & $0.197^{* *}$ & 0.522 \\
\hline
\end{tabular}

Diagonal: AVE, below diagonal: correlation between variables, above diagonal: Square of correlation between variables. ${ }^{*} p<0.05,{ }^{* *} p<0.01$.

Then, we proceeded to test hypotheses after confirming the reliability and validity of our data. Structural equation modeling analysis was conducted to test our hypotheses. Hypothesis 1 and 2 stated that the congruency between ideal self and brand image, and congruency between ideal social self and brand image have positive effects on brand identification. Path coefficients for the effect of ideal self-brand image congruency and ideal social self-brand image congruency on brand identification are positive and significant $(\beta=0.416, p<0.01 ; \beta=0.217, p<0.01)$, which supports Hypothesis 1 and 2 . Additionally, the path coefficient for the effect of brand identification on positive emotions is positive and significant $(\beta=0.572, p<0.01)$, which supports Hypothesis 3 . Lastly, analysis showed that positive emotions have a significantly positive effect on happiness $(\beta=0.241, p<0.01)$, which is in support of Hypothesis 4 . Table 4 shows the summary of the hypotheses test results.

Table 4. Summary of the hypotheses test results.

\begin{tabular}{lccc}
\hline \multicolumn{1}{c}{ Hypothesis (Path) } & Path Coefficient & $t$-Value & Accepted or Not \\
\hline H1: Ideal self-brand congruency $\rightarrow$ Brand identification & $0.416^{* *}$ & 4.944 & Accepted \\
H2: Ideal social self-brand congruency $\rightarrow$ Brand identification & $0.217^{* *}$ & 2.594 & Accepted \\
H3: Brand identification $\rightarrow$ Positive emotions & $0.572^{* *}$ & 7.188 & Accepted \\
H4: Positive emotions $\rightarrow$ Happiness & $0.241^{* *}$ & 2.941 & Accepted \\
\hline \multicolumn{2}{r}{$p<0.01}$. & &
\end{tabular}

\subsection{Two-Mediation Test}

After confirming that the proposed hypotheses were supported, we proceeded to conduct two-mediation analysis to check whether our proposed mediators, brand identification, and positive emotion, fully or partially, mediate ideal self-brand congruency and happiness. To this end, the data were submitted to a multistep mediation analysis with two sequential mediators. Figure 2 shows the model of multistep mediation analysis. As shown in Figure 2, the dependent variable $(\mathrm{Y})$ was the feeling of happiness. The potential mediators were the brand identification $\left(\mathrm{M}_{1}\right)$ and the positive emotions $\left(\mathrm{M}_{2}\right)$. The independent variables $(\mathrm{X} 1 / \mathrm{X} 2)$ were ideal self-brand congruency and ideal social self-brand congruency. 


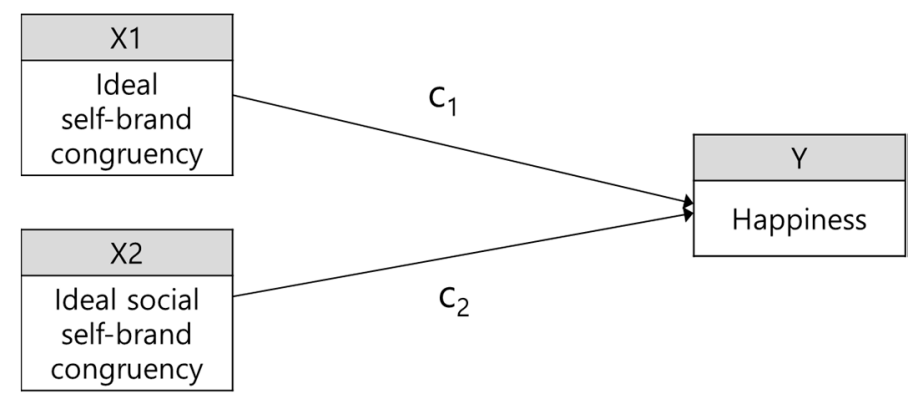

(a) Total effect model

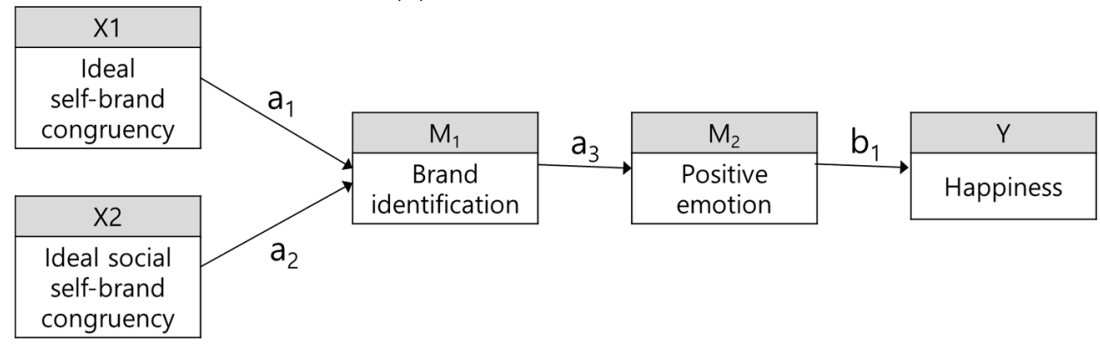

(b) Full mediation model

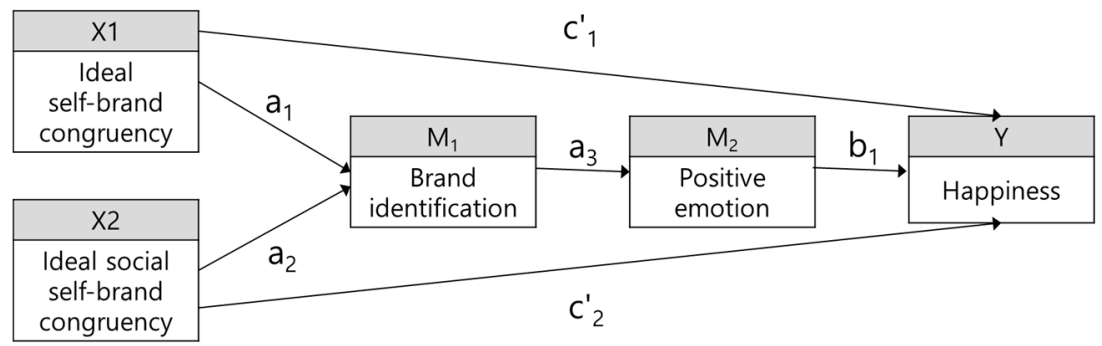

(c) Partial mediation model

Figure 2. Multistep mediation model.

First, the total-effect model confirmed a non-significant relationship between brand ideal self/ideal social self-brand congruency and happiness $(\beta 11=0.121$, S.E $=0.063, p=0.135$, C.R. $=1.495 / \beta 12=-0.033$, S.E $=0.075, p=0.685$, and C.R. $=-0.405)$. This means that ideal self $/$ ideal social self-brand congruency did not directly affect happiness. Previous studies propose that there is no need to have a significant relationship between independent variables and dependent variables when verifying the mediating effect $[43,44]$. Therefore, we continued to conduct the following mediation model analysis.

Second, the results of full mediation model confirmed the proposed chain of mediators, brand identification $\left(\mathrm{M}_{1}\right)$, and positive emotion $\left(\mathrm{M}_{2}\right)$, mediate the relationship between ideal self/ideal social self-brand congruency and happiness. As shown in Table 5, both ideal self-brand congruency and ideal social self-brand congruency influence the brand identification $\left(\mathrm{a}_{1}=0.416, \mathrm{~S} . \mathrm{E}=0.096, p=0.000\right.$, C.R. $=4.944 / \mathrm{a}_{2}=0.297, \mathrm{~S} . \mathrm{E}=0.114, p=0.009$, and C.R. $\left.=2.594\right)$, brand identification influences the positive emotions $\left(a_{3}=0.572\right.$, S.E $=0.062, p=0.000$, and C.R. $\left.=7.188\right)$, and positive emotions influence happiness $\left(b_{1}=0.241, S . E=0.072, p=0.003\right.$, and C.R. $\left.=2.941\right)$. In addition, the value of the mediating effect was computed by the bias-corrected bootstrapping method, indicating that the mediating effect was significantly different from zero at $p<0.05$, as the CI did not contain zero. The $95 \%$ CI for the indirect effect was obtained with 5000 bootstrap resamples and supported the suggested multistep mediation. As a result, as shown in Table 6, the indirect effects were significant. 
Table 5. Model-path estimates.

\begin{tabular}{|c|c|c|c|c|}
\hline & & Total Effect Model & Full Mediation Model & Partial Mediation Model \\
\hline \multirow{4}{*}{ Model fit } & CMIN & 260.572 & 444.230 & 443.222 \\
\hline & DF & 63 & 204 & 202 \\
\hline & $\mathrm{P}$ & 0.000 & 0.000 & 0.000 \\
\hline & $\mathrm{CMIN} / \mathrm{P}$ & 4.136 & 2.178 & 2.194 \\
\hline \multirow{6}{*}{ Coefficient } & $X 1->Y$ & $\mathrm{c}_{1}=0.121$ (n.s) & - & $\mathrm{c}^{\prime}{ }_{1}=0.065$ (n.s) \\
\hline & $X 2->Y$ & $c_{2}=-0.033$ (n.s) & - & $\mathrm{c}^{\prime}{ }_{2}=-0.095$ (n.s) \\
\hline & $\mathrm{X} 1->\mathrm{M} 1$ & - & $\mathrm{a}_{1}=0.416^{* *}$ & $\mathrm{a}_{1}=0.416^{* *}$ \\
\hline & X2->M1 & - & $\mathrm{a}_{2}=0.217^{* *}$ & $\mathrm{a}_{2}=0.217^{*}$ \\
\hline & $\mathrm{M}_{1}->\mathrm{M}_{2}$ & - & $\mathrm{a}_{3}=0.572 * *$ & $\mathrm{a}_{3}=0.572 * *$ \\
\hline & $\mathrm{M}_{2}->\mathrm{Y}$ & - & $\mathrm{b}_{1}=0.241^{* *}$ & $\mathrm{~b}_{1}=0.251^{* *}$ \\
\hline
\end{tabular}

Table 6. Results of indirect effects (full mediation model).

\begin{tabular}{|c|c|c|c|c|c|c|c|c|}
\hline \multirow{2}{*}{$\begin{array}{l}\text { Dependent } \\
\text { Variable }\end{array}$} & \multirow{2}{*}{$\begin{array}{l}\text { Independent } \\
\text { Variable }\end{array}$} & \multirow{2}{*}{$\begin{array}{l}\text { Mediating } \\
\text { Variable } 1\end{array}$} & \multirow{2}{*}{$\begin{array}{l}\text { Mediating } \\
\text { Variable } 2\end{array}$} & \multirow{2}{*}{$\begin{array}{l}\text { Indirect } \\
\text { Effect }\end{array}$} & \multirow[t]{2}{*}{ SD } & \multirow[t]{2}{*}{$p$-Value } & \multicolumn{2}{|c|}{$\begin{array}{c}\text { Confidence } \\
\text { Interval } 95 \%\end{array}$} \\
\hline & & & & & & & LLCI & ULCI \\
\hline \multirow{2}{*}{ Happiness } & $\begin{array}{c}\text { Ideal } \\
\text { self-brand } \\
\text { congruency }\end{array}$ & \multirow{2}{*}{$\begin{array}{c}\text { Brand } \\
\text { identification }\end{array}$} & \multirow{2}{*}{$\begin{array}{l}\text { Positive } \\
\text { emotions }\end{array}$} & 0.057 & 0.020 & 0.001 & 0.015 & 0.096 \\
\hline & $\begin{array}{l}\text { Ideal social } \\
\text { self-brand } \\
\text { congruency }\end{array}$ & & & 0.030 & 0.016 & 0.006 & 0.006 & 0.075 \\
\hline
\end{tabular}

Finally, the results of partial mediation model are as follows. As shown in Table 5, both ideal self-brand congruency/Ideal social self-brand congruency influence brand identification $\left(\mathrm{a}_{1}=0.416\right.$, S.E $=0.096, p=0.000$, C.R. $=4.947 / \mathrm{a}_{2}=0.217, \mathrm{~S} . \mathrm{E}=0.114, p=0.010$, and C.R. $\left.=2.591\right)$, the brand identification influences positive emotions $\left(\mathrm{a}_{3}=0.572\right.$, S.E $=0.062, p=0.000$, and C.R. $\left.=7.188\right)$, and the positive emotions influence happiness $\left(b_{1}=0.251\right.$, S.E $=0.077, p=0.004$, and C.R. $\left.=2.899\right)$. However, there was a non-significant relationship between ideal self/ideal social self-brand congruency and happiness $\left(\mathrm{c}_{1}{ }_{1}=0.065, \mathrm{~S} . \mathrm{E}=0.076, p=0.501, \mathrm{C} . \mathrm{R} .=0.673 / \mathrm{c}_{2}{ }_{2}=-0.095, \mathrm{~S} . \mathrm{E}=0.090, p=-0.994\right.$, and C.R. $=0.320$ ). The $95 \% \mathrm{CI}$ for the indirect effect was obtained with 5,000 bootstrap resamples and supported the suggested multistep mediation (X1-> $\mathrm{M}_{1-}>\mathrm{M}_{2}->\mathrm{Y}$ path coefficient is $0.047,95 \% \mathrm{CI}, 0.016$ to 0.104 , and $X 2->\mathrm{M}_{1}->\mathrm{M}_{2}->\mathrm{Y}$ path coefficient was $0.079,95 \% \mathrm{CI}, 0.006$ to 0.079$)$ [44]. No other indirect effects were significant.

As a result of the comparison of the three models above, the model fit of full mediation model was higher than that of partial mediation model. In sum, there is no direct effect of ideal self/ideal social self-brand congruency and happiness on the partial mediation model, and the indirect effect through brand identification and positive emotions is significant. Based on the results of the mediation analysis, we confirmed that there are full mediation effects of brand identification and positive emotions between ideal self/ideal social self-brand congruency and happiness.

\section{Discussion}

In this study, we examine how congruency between ideal self-concepts (ideal self-image and ideal social self-image) and brand image positively influences happiness by applying the Sustainable Happiness Model. As expected, we found that when ideal self-image and ideal social self-image are congruent with brand image, a sense of happiness can be enhanced through brand identification and positive emotions.

The findings of this study can provide useful and noble insights by showing that the Sustainable Happiness Model can be applied to brand research. That is, a consumer can feel enhanced happiness 
through a brand that is congruent with his/her ideal self or ideal social self. We believe that this study can contribute to the literature by revealing the mechanism of how congruency between ideal self-image and brand image positively affect happiness. In addition, the results of further two-mediation analysis provide strong support for our proposed conceptual model and underlying psychological mechanism of how ideal self-brand congruency ultimately increases consumer happiness. That is, congruency between ideal self-concepts and brand image does not directly increase happiness, but only through brand identification and positive emotions. No prior study, to the best of our knowledge, has aimed to find out the mediating process between ideal self/ideal social self-brand congruency and consumer happiness by applying the Sustainable Happiness Model.

We believe that our proposed conceptual model, based on the Sustainable Happiness Model in this study, is linked to 'enriching benefits' from the theory of brand's 3E benefits. The theory posits that there are three types of benefits (enabling, enticing, and enriching benefits) that a brand has for consumers [45]. According to the theory, strong enriching benefits of a brand enriches consumers by resonating with their sense of self (who they are, who they were, and who they want to be). As this is consistent with congruency between ideal self-concepts and brand image in our conceptual model in a sense, we may be able to expect the possibility that the Sustainable Happiness Model can be applied to the theory of brand's 3E benefit and thus further explore the enriching benefits of a brand for consumer well-being.

Enhancing consumer happiness is also closely related to the long-term sustainability of a business. This means that our findings can also provide important managerial implications for business practitioners. A company's marketing efforts have been criticized for unnecessary and provocative advertising and pushing consumers to spend more money. The criticism calls for heightened social responsibility of marketing practices [6]. In this regard, our findings are able to suggest new directions for the marketing strategy of a company. A company can practice effective marketing strategy and positively influence consumers' happiness at the same time by reflecting consumers' ideal self-concepts in the process of developing brand image. In addition, extant studies indicate that enhancing customer well-being can help firms achieve higher financial performance in the long-term [3-5]. For example, Lee and Sirgy [6] suggest the concept of quality-of-life (QOL) marketing. QOL marketing is defined as marketing practice designed to enhance customer well-being while preserving the well-being of other stakeholders [46,47]. The concept of QOL marketing has been discussed in a variety of contexts to improve the long-term sustainability of businesses [6]. In this light, as a previous study also suggests [48], we believe that our findings can also make managerial contributions by suggesting one of the effective ways of how to enhance customer well-being through branding strategy.

While this study made contributions, it has some limitations that further research should address. First, we propose our conceptual model of how congruency between ideal self-concepts and brand image enhances consumer happiness through psychological mechanisms of brand identification and positive emotions. However, it is possible that other psychological mechanisms also exist between ideal self/ideal social self-brand congruency and consumer happiness. Further studies may need to find out the other potential psychological mechanisms and to more deeply understand the relationship between ideal self/ideal social self-brand congruency and consumer happiness. Second, since we apply the Sustainable Happiness Model, which argues the role of presenting ideal self-concepts on enhancing happiness, we focus on the positive effect of ideal self/ideal social self-brand congruency on happiness. However, according to self-discrepancy theory [49], the gap between actual self and ideal self can generate negative feelings. If the ideal self is excessively presented, there is a possibility that the gap between the actual self and the ideal self becomes large, which leads to a negative result. This may decrease the sense of happiness. Thus, it would be interesting to simultaneously examine the positive and negative effect of presenting ideal self on happiness in further studies. In addition, since respondents who participated in our study are all Asian, it would be worthwhile if further studies examined cultural differences on the effect of presenting ideal self on happiness for a deeper understanding. 
Author Contributions: J.H. and M.J. designed the research framework and wrote the paper. M.K. and S.K. analyzed the data and edited the paper.

Funding: This work was supported by the Ministry of Education of the Republic of Korea and the National Research Foundation of Korea (NRF-2016S1A5B5A01023312).

Conflicts of Interest: The authors declare no conflicts of interest.

\section{References}

1. Lyubomirsky, S.; Sheldon, K.M.; Schkade, D. Pursuing happiness: The architecture of sustainable change. Rev. Gen. Psychol. 2005, 9, 111-131. [CrossRef]

2. Kotler, P.; Kartajaya, H.; Setiawan, I. Marketing 3.0: From Products to Customers to the Human Spirit; John Wiley \& Sons: Hoboken, NJ, USA, 2010.

3. Collins, M. Global corporate philanthropy-marketing beyond the call of duty? Eur. J. Mark. 1993, $27,46-58$. [CrossRef]

4. Kalwani, M.U.; Narayandas, N. Long-term manufacturer-supplier relationships: Do they pay off for supplier firms? J. Mark. 1995, 59, 1-16. [CrossRef]

5. Naidu, G.M.; Parvatiyar, A.; Sheth, J.N.; Westgate, L. Does relationship marketing pay? An empirical investigation of relationship marketing practices in hospitals. J. Bus. Res. 1999, 46, 207-218. [CrossRef]

6. Lee, D.J.; Sirgy, M.J. Quality-of-life (QOL) marketing: Proposed antecedents and consequences. J. Macromark. 2004, 24, 44-58. [CrossRef]

7. Sheldon, K.M.; Lyubomirsky, S. Change Your Actions, Not Your Circumstances: An Experimental Test of the Sustainable Happiness Model; Happiness, Economics, and Politics: Towards a Multi-Disciplinary Approach; Edward Elgar Pub: Cheltenham, UK, 2009; pp. 324-342.

8. Lazzari, R.; Fioravanti, M.; Gough, H.G. A new scale for the adjective check list based on self vs. ideal-self discrepancies. J. Clin. Psychol. 1978, 34, 361-365. [CrossRef]

9. Wylie, R.C. The Self-Concept: Theory and Research on Selected Topics; U of Nebraska Press: Lincoln, LS, USA, 1974.

10. Sirgy, M.J. Self-concept in consumer behavior: A critical review. J. Consum. Res. 1982, 9, 287-300. [CrossRef]

11. Aaker, J.L. The malleable self: The role of self-expression in persuasion. J. Mar. Res. 1999, 36, 45-57. [CrossRef]

12. Grohmann, B. Gender dimensions of brand personality. J. Mar. Res. 2009, 46, 105-119. [CrossRef]

13. Malär, L.; Krohmer, H.; Hoyer, W.D.; Nyffenegger, B. Emotional brand attachment and brand personality: The relative importance of the actual and the ideal self. J. Mark. 2011, 75, 35-52. [CrossRef]

14. Hughes, D.E.; Ahearne, M. Energizing the reseller's sales force: The power of brand identification. J. Mark. 2010, 74, 81-96. [CrossRef]

15. Tuškej, U.; Golob, U.; Podnar, K. The role of consumer-brand identification in building brand relationships. J. Bus. Res. 2013, 66, 53-59. [CrossRef]

16. Kim, C.K.; Han, D.; Park, S.B. The effect of brand personality and brand identification on brand loyalty: Applying the theory of social identification. Jpn. Psychol. Res. 2001, 43, 195-206. [CrossRef]

17. Stokburger-Sauer, N.; Ratneshwar, S.; Sen, S. Drivers of consumer-brand identification. Int. J. Res. Mark. 2012, 29, 406-418. [CrossRef]

18. Wetzel, C.G.; Insko, C.A. The similarity-attraction relationship: Is there an ideal one? J. Exp. Soc. Psychol. 1982, 18, 253-276. [CrossRef]

19. Herbst, K.C.; Gaertner, L.; Insko, C.A. My head says yes but my heart says no: Cognitive and affective attraction as a function of similarity to the ideal self. J. Pers. Soc. Psychol. 2003, 84, 1206-1219. [CrossRef] [PubMed]

20. LaPrelle, J.; Hoyle, R.H.; Insko, C.A.; Bernthal, P. Interpersonal attraction and descriptions of the traits of others: Ideal similarity, self-similarity, and liking. J. Res. Pers. 1990, 24, 216-240. [CrossRef]

21. Aron, A.; Fisher, H.; Mashek, D.J.; Strong, G.; Li, H.; Brown, L.L. Reward, motivation, and emotion systems associated with early-stage intense romantic love. J. Neurophysiol. 2005, 94, 327-337. [CrossRef] [PubMed]

22. Fournier, S. Consumers and their brands: Developing relationship theory in consumer research. J. Consum. Res. 1998, 24, 343-373. [CrossRef] 
23. McEwen, W.J. Married to the Brand: Why Consumers Bond with Some Brands for Life; Gallup Press: New York, NY, USA, 2005.

24. Patrick, H.; Knee, C.R.; Canevello, A.; Lonsbary, C. The role of need fulfillment in relationship functioning and well-being: A self-determination theory perspective. J. Pers. Soc. Psychol. 2007, 92, 434. [CrossRef] [PubMed]

25. Branscombe, N.R.; Wann, D.L. The positive social and self concept consequences of sports team identification. J. Sport Soc. Issues 1991, 15, 115-127. [CrossRef]

26. Watson, D.; Clark, L.A. Negative affectivity: The disposition to experience aversive emotional states. Psychol. Bull. 1984, 96, 465-490. [CrossRef] [PubMed]

27. Cohn, M.A.; Fredrickson, B.L.; Brown, S.L.; Mikels, J.A.; Conway, A.M. Happiness unpacked: Positive emotions increase life satisfaction by building resilience. Emotion 2009, 9, 361-368. [CrossRef] [PubMed]

28. Ashby, F.G.; Isen, A.M. A neuropsychological theory of positive affect and its influence on cognition. Psychol. Rev. 1999, 106, 529. [CrossRef] [PubMed]

29. Isen, A.M. Positive affect, cognitive processes, and social behavior. Adv. Exp. Soc. Psychol. 1987, 2, $203-253$. [CrossRef]

30. Aspinwall, L.G. Rethinking the role of positive affect in self-regulation. Motiv. Emot. 1998, $22,1-32$. [CrossRef]

31. Folkman, S.; Moskowitz, J.T. Positive affect and the other side of coping. Am. Psychol. 2000, 55, 647. [CrossRef] [PubMed]

32. Fredrickson, B.L. Cultivating positive emotions to optimize health and well-being. Prev. Treat. 2000, 3, 1-25. [CrossRef]

33. Snyder, C.R.; Shane, L.; Jennifer, P. Positive Psychology; Oxford University Press: New York, NY, USA, 2011.

34. Cohen, S.; Pressman, S.D. Positive affect and health. Curr. Dir. Psychol. Sci. 2006, 15, 122-125. [CrossRef]

35. Diener, E.; Wolsic, B.; Fujita, F. Physical attractiveness and subjective well-being. J. Pers. Soc. Psychol. 1995, 69. [CrossRef]

36. Kent, R.J.; Allen, C.T. Competitive interference effects in consumer memory for advertising: The role of brand familiarity. J. Mark. 1994, 97-105. [CrossRef]

37. Sirgy, M.J.; Grewal, D.; Mangleburg, T.F.; Park, J.O.; Chon, K.S.; Claiborne, C.B.; Berkman, H. Assessing the predictive validity of two methods of measuring self-image congruence. J. Acad. Mark. Sci. 1997, 25, 229-241. [CrossRef]

38. Kuenzel, S.; Vaux Halliday, S. Investigating antecedents and consequences of brand identification. J. Prod. Brand Manag. 2008, 17, 293-304. [CrossRef]

39. Richins, M.L. Measuring emotions in the consumption experience. J. Consum. Res. 1997, 24, 127-146. [CrossRef]

40. Diener, E.D.; Emmons, R.A.; Larsen, R.J.; Griffin, S. The satisfaction with life scale. J. Pers. Assess. 1985, 49, 71-75. [CrossRef] [PubMed]

41. Lyubomirsky, S.; Lepper, H.S. A measure of subjective happiness: Preliminary reliability and construct validation. Soc. Indic. Res. 1999, 46, 137-155. [CrossRef]

42. Fornell, C.D.; Larcker, F. Evaluating structural equation models with unobservable variables and measurement errors. J. Mark. Res. 1981, 18, 39-50. [CrossRef]

43. Kenny, D.A.; Kashy, D.A.; Bolger, N. Data analysis in social psychology. In The handbook of Social Psychology; Gilbert, D., Fiske, S., Lindzey, G., Eds.; McGraw-Hill: New York, NY, USA, 1998; pp. 233-265.

44. Preacher, K.J.; Hayes, A.F. Asymptotic and resampling strategies for assessing and comparing indirect effects in multiple mediator models. Behav. Res. Methods 2008, 40, 879-891. [CrossRef] [PubMed]

45. Park, C.W.; MacInnis, D.J.; Eisingerich, A.B. Brand Admiration: Building a Business People Love; John Wiley \& Sons: Hoboken, NJ, USA, 2016.

46. Sirgy, M.J.; Lee, D.J. Setting socially responsible marketing objectives: A quality-of-life approach. Eur. J. Mark. 1996, 30, 20-34. [CrossRef]

47. Sirgy, M.J. An ethical marketing perspective. In Handbook of Quality-of-Life Research; Springer Science \& Business Media: New York, NY, USA, 2001; Volume 8. 
48. Fukuda, S.; Murakami, M.; Noda, K.; Oki, T. How achieving the Millennium Development Goals increases subjective well-being in developing nations. Sustainability 2016, 8, 189. [CrossRef]

49. Higgins, E.T. Self-discrepancy: A theory relating self and affect. Psychol. Rev. 1987, 94, 319-340. [CrossRef] [PubMed]

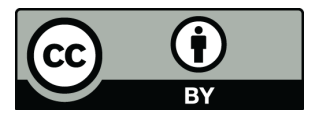

(C) 2018 by the authors. Licensee MDPI, Basel, Switzerland. This article is an open access article distributed under the terms and conditions of the Creative Commons Attribution (CC BY) license (http:/ / creativecommons.org/licenses/by/4.0/). 